\title{
REBREATHING AND CARBON DIOXIDE ELIMINATION WITH THE BAIN CIRCUIT
}

\author{
Wolfgang E. SPoErel
}

ABstract

The carbon dioxide distribution inside the Bain breathing circuit was measured during controlled ventilation in 14 patients. A circuit with seven equi-distant sampling ports was constructed and gas samples were also taken at the gas machine end of the circuit and from a catheter ending near the tip of the tracheal tube. The carbon dioxide concentration was measured with a mass spectromcter. After $\mathbf{3 0}$ minutes of a stable halothane or ethrane anaesthesia, the maximum and minimum carbon dioxide concentration was determined at each sampling site; after that either tidal volume, inspiration to expiration ratio, respiratory rate (with and without change in minute ventilation) or fresh gas flow were changed, keeping all other parameters constant. The carbon dioxide measurements were repeated after an interval of at least 20 minutes. Each change was recorded in at least two patients. Only qualitative changes obtained in an individual patient were compared.

The results indicate that in conditions where the expired minute volume $(\dot{V} E)$ was greater than the volume of fresh gas entering the circuit $\left(\grave{V}_{F}\right)$, end-tidal carbon dioxide concentration $\left(\mathrm{FET}_{\mathrm{CO}_{2}}\right)$ and the mean carbon dioxide concentration in gas eliminated from the circuit $\left(\mathrm{FE}_{\mathrm{CO}_{2}}\right)$ depended only on $\dot{V}_{F}$ and its utilization. The lowest inspired carbon dioxide concentration $\left(\mathrm{F}_{\mathrm{CO}_{2}}\right)$ could be varied independent of $\mathrm{FET} \mathrm{CO}_{2}$ and $\mathrm{F}_{\mathrm{CO}_{2}}$ by changing respiratory rate (with or without changing $V_{E}$ ), tidal volume or the inspiratory:expiratory ratio, all of which influence the degree of rebreathing or mixing of expired and fresh gas within the circuit. The $\mathrm{FI}_{\mathrm{I} \mathrm{O}_{2}}$ will rise toward the $\mathrm{F}_{\mathrm{CO}_{2}}$ as mixing becomes more complete. Although an increase in $\dot{\mathrm{V}}_{\mathrm{F}}$ (providing $\left.V_{E}>V_{F}\right)$ did lower $\mathrm{FET}_{\mathrm{CO}_{2}}, \mathrm{FE}_{\mathrm{CO}_{2}}$ and $\mathrm{FI}_{\mathrm{CO}_{2}}$, the reduction of the latter did not correspond to the fall in $\mathrm{FET}_{\mathrm{CO}_{2}}$.

It is concluded that, with controlled ventilation, the distribution of carbon dioxide within the Bain circuit and the $\mathrm{FI}_{\mathrm{CO}_{2}}$ have no influence on the alveolar carbon dioxide concentration or the carbon dioxide elimination from the circuit.

IN SPITE OF THE SIMPLICITY of the Bain breathing circuit $^{1}$ as a modification of Mapleson's system $D,{ }^{2}$ the distribution of carbon dioxide within the circuit and its effects on carbon dioxide elimination from the patient through the circuit are still a matter of debate. The detection of carbon dioxide in the inspired gas is an indication of rebreathing and rebreathing is thought to be synonymous with inadequate elimination of carbon dioxide and hypercarbia and, therefore, undesirable. ${ }^{3-8}$ To avoid rebreathing, it has been advocated that the circuit should be converted to a nonrebreathing system, as much as possible, by using fresh gas flows of two to three times greater than the patient's resting minute ventilation. ${ }^{3-8}$ However, clinical experience has demonstrated that with the Mapleson D system normocapnia can be maintained with fresh gas flows of $70 \mathrm{ml} \cdot \mathrm{kg}^{-1}$ $\min ^{-1}$, well below the resting minute ventilation and close to the alveolar ventilation, ${ }^{9-15}$ provided that the volume of ventilation is greater than the

Wolfgang E. Spoerel, M.D., F.R.C.P.(C), Professor and Chairman, Department of Anaesthesia, University of Western Ontario, University Hospital, London, Canada.

Canad. Anaesth. Soc. J., vol. 27, no. 4, July 1980 volume of fresh gas entering the circuit. Such conditions are not possible without considerable rebreathing.

Much of the theoretical objection to the Bain circuit is based on the demonstration of a raised inspired carbon dioxide level due to rebreathing, ${ }^{5,6,8}$ and has resulted in the recommendation of a high fresh gas flow to keep inspired carbon dioxide below a prescribed "safe" level. ${ }^{6}$ This view presupposes that in a Mapleson D system the inspired carbon dioxide concentration will directly influence the alveolar level and that a low inspired carbon dioxide is required for adequate carbon dioxide elimination.

Since this assumption did not agree with clinical observations, I decided to determine the distribution of carbon dioxide within the trachea and the breathing system during controlled ventilation and to examine the relationship between the end-tidal concentration ( $\mathrm{FET}_{\mathrm{CO}_{2}}$ ), the lowest inspired concentration $\left(\mathrm{Fi}_{\mathrm{CO}_{2}}\right)$ and the mean concentration in gas eliminated from the circuit $\left(\mathrm{FE}_{\mathrm{CO}_{2}}\right)$ as influenced by changes in respiratory rate (RR), minute ventilation ( $\left.\dot{V}_{E}\right)$, volume of fresh gas $\left(\dot{V}_{F}\right)$ and inspiratory to expiratory ratio. 


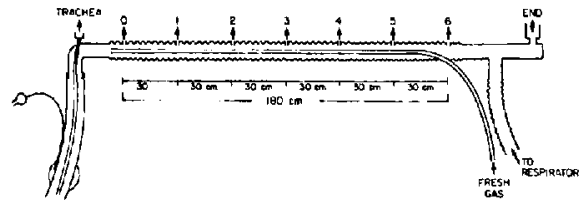

FiguRE I Bain breathing system prepared for sampling (see text).

\section{METhOD}

A Bain circuit was prepared with ports for gas sampling, located $30 \mathrm{~cm}$ apart along the $1.8 \mathrm{~m}$ breathing tube (Figure 1). In addition, gas was sampled from the trachea through a fine plastic catheter introduced through the elbow connector and also from a port at the machine end of the circuit, located near the connection with the ventilator, as shown in Figure I. The sampling tube of an Elmer-Perkins mass spectrometer was moved from port to port in a quick sequence, recording about five respiratory cycles each time. All unused ports were kept closed. The volume of suction of the mass spectrometer was approximately $80 \mathrm{ml} \cdot \mathrm{min}^{-1}$, which is less than two per cent of the gas flow and should not influence the values recorded. The volume of the breathing circuit between ports was approxinately $100 \mathrm{ml}$.

The measurements described were taken on 14 adult patients with no known pulmonary pathology during routine surgical procedures suitable for the maintenance of constant conditions of anaesthesia and carbon dioxide output. All patients were anaesthetized with halothane 1.0 per cent or ethrane 1.5 per cent and nitrous oxide and oxygen at a ratio of about 5:2. After constant conditions of anaesthesia and controlled ventilation with an Air-Shields Ventimeter-Ventilator for at least 30 minutes, an initial sampling sequence was taken and immediately afterwards the expired minute volume (VE) was rechecked with a Wright respirometer, temporarily interposed between circuit and tracheal tube. Thereafter one of the following parameters was changed: tidal volume, RR (with or without a change in $\dot{V}_{E}$ ), inspiratory:expiratory ratio or $\dot{V}_{F}$. The sampling sequence was repeated after at least 20 minutes had elapsed since the change. Not more than two variables were tested in a single patient and, when the time of the operation permitted, the same changes were repeated.

Since the main purpose of this paper is to show the relationship between $\mathrm{FI}_{\mathrm{CO}_{2}}, \mathrm{FET}_{\mathrm{CO}_{2}}$ and $\mathrm{F} \overline{\mathrm{E}}_{\mathrm{CO}_{2}}$, only qualitative changes in response to alteration in parameters of ventilation are reported. A quantitative analysis was felt unnecessary as it would only contribute complexity. Each of the observations presented in Figures 2 to 7 was verified in at least two other patients.

\section{Results}

An actual, but compressed, recording of the carbon dioxide concentrations throughout the breathing system is shown in Figure $2 \mathrm{~A}$. In the trachea, the maximum carbon dioxide concentration corresponded to the end-tidal carbon dioxide $\left(\mathrm{FET}_{\mathrm{CO}_{2}}\right)$, while the lowest recordable concentration $\left(\mathrm{FI}_{\mathrm{CO}_{2}}\right.$ ) was in the early inspiratory phase. Maximum and minimum carbon dioxide values were lowest at sampling port 0 close to the site of fresh gas inflow. Distal to this point (as seen from the patient) there was a large difference between high and low carbon dioxide concentrations at sampling sites $I$ and 2, indicating the presence of a bolus of fresh gas just before inspiration. Further distal, this fresh gas became increasingly mixed with expired gas (sampling site 3-5) and the difference between maximum and minimum carbon dioxide concentration had decreased to less than one volume per cent at sampling port 6 . A short side arm interposed between the machine end of the circuit and the sampling port marked "End" (Figure 1), completed this mixing process and gas with a nearly uniform carbon dioxide concentration $\left(\mathrm{FE}_{\mathrm{CO}_{2}}\right)$ emerged from this port, equivalent in composition to gas vented from the circuit.

While the recording in Figure $2 \mathrm{~A}$ was representative for a slow ventilation with large tidal volumes (RR $8 \cdot \mathrm{min}^{-1}$, VE $8.8 \mathrm{l} \cdot \mathrm{min}^{-1}$ ), an increase in RR to $17 \cdot \mathrm{min}^{-1}$, without changing tidal

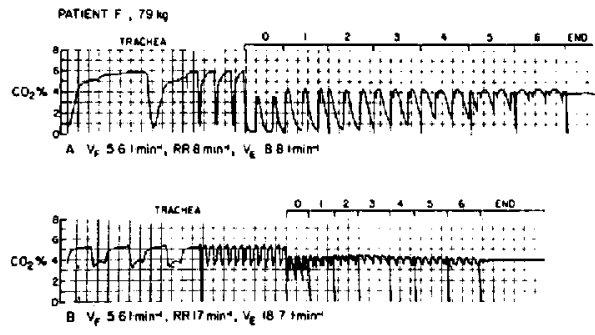

FIGURE 2 Example of recording of carbon dioxide distribution according to sampling ports indicated in Figure 1. Change from respiratory rate of $8 \cdot \min ^{-1}(A)$ to $17 \cdot \min ^{-1}(B)$. Note that the end-tidal carbon dioxide (FET $\mathrm{CO}_{2}$ ) in $\mathrm{B}$ is lower, while the lowest carbon dioxide concentration during inspiration $\left(\mathrm{FI}_{\mathrm{CO}_{2}}\right)$ is clevated compared to $A$ 

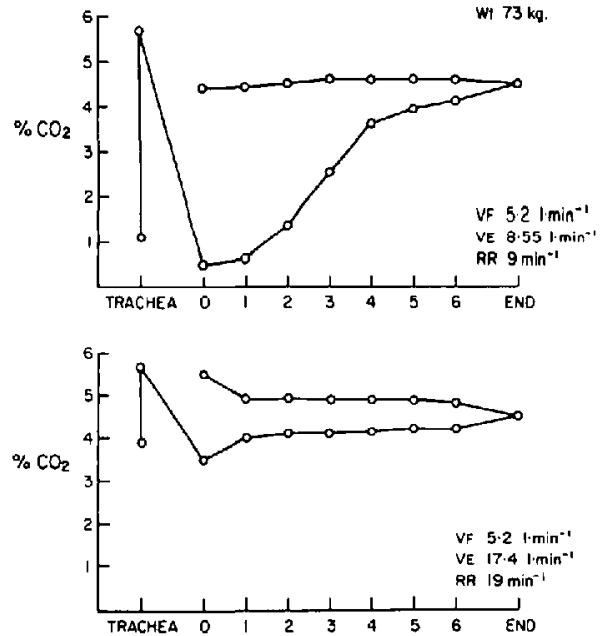

FIGURE 3 Schematic representation of maximum and minimum carbon dioxide concentrations measured at sampling ports shown in Figure 1 . Increase of RR from $9 \cdot \min ^{-1}$ (upper graph) to $19 \cdot \min ^{-1}$ (lower graph) produced changes similar to those in Figure 2.

volume or $\dot{V}_{F}$, produced a very different pattern (Figure 2B): In the trachea $\mathrm{FET}_{\mathrm{CO}_{2}}$ decreased slightly (from 5.9 volumes per cent to 5.4 volumes per cent) but $\mathrm{Fl}_{\mathrm{CO}_{2}}$ rose from 0.6 volumes per cent to 3.2 volumes per cent; the bolus of fresh gas near the inflow site disappeared and there was marked mixing of gases within the circuit, so that the difference between high and low carbon dioxide values was less than one volume per cent between sampling ports 1 to 6 ; however, the $\mathrm{FE}_{\mathrm{CO}_{2}}$ remained unchanged.

A schematic representation of the carbon dioxide recording, giving the high and low values of each sampling site, shows again the effect of an increase in $V_{E}$ by raising the respiratory rate in another patient (Figure 3).

$\mathrm{FET}_{\mathrm{CO}_{2}}$ and $\mathrm{FI}_{\mathrm{CO}_{2}}$ could be changed in opposite directions (Figure 4). When the incomplete utilization ( $\left.\dot{V}_{E}: \dot{V}_{F}=1.2\right)$ of fresh gas, which had resulted in a slightly elevated $\mathrm{FEr}_{\mathrm{CO}_{2}}$, was improved by raising the tidal volume only, the FET $\mathrm{CO}_{2}$ fell while the $\mathrm{FI}_{\mathrm{CO}_{2}}$ increased.

The response to an increase in $\dot{V F}_{F}$ is shown in Figure 5. Here the $\mathrm{FET}_{\mathrm{CO}_{2}}$ decreased and so did the $\mathrm{F} \bar{E}_{\mathrm{CO}_{2}}$. There was little change in the degree of mixing within the circuit and the $\mathrm{FI}_{\mathrm{CO}_{2}}$ dropped less than the $\mathrm{FET}_{\mathrm{CO}}$.

An increase in respiratory rate only, while keeping $\dot{V}_{E}$ nearly constant and $\dot{V}_{F}$ unchanged (Figure 6), resulted in increased mixing within the
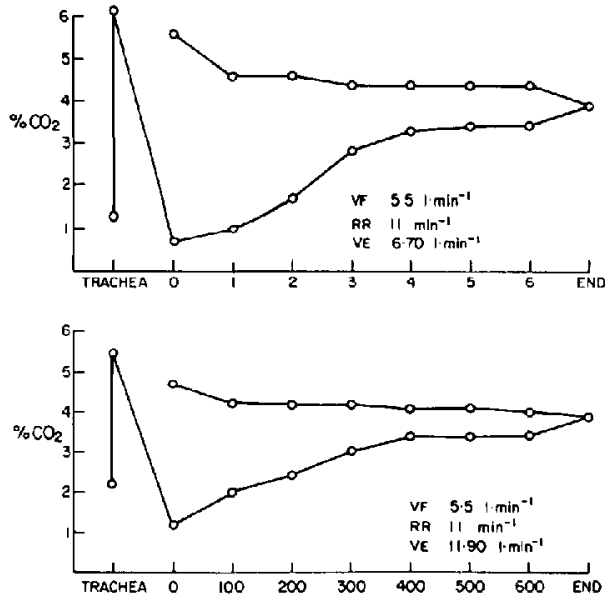

Figure 4 Carbon dioxide concentrations in Bain circuit in $78 \mathrm{~kg}$ patient: change in VE only. While FET decreased from 6.1 to 5.7 volumes per cent $\mathrm{Fl}_{\mathrm{co}_{2}}$ increased from 1.2 to 2.1 volumes per cent.
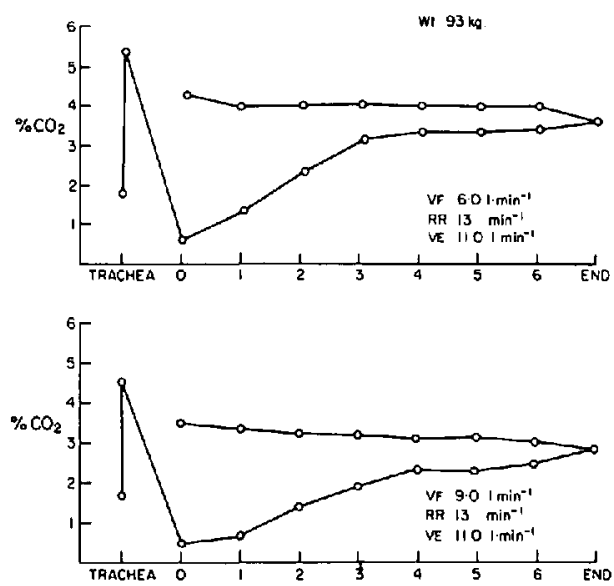

Figure 5 Maximum and minimum carbon dioxide concentration inside Bain circuit and changes produced by increased fresh gas flow. Note that there is a greater reduction in $\mathrm{FET}_{\mathrm{CO}_{2}}$ than in $\mathrm{FI}_{\mathrm{CO}_{2}}$.

circuit, associated with a rise in $\mathrm{Fl}_{\mathrm{CO}_{2}}$, but $\mathrm{FET}_{\mathrm{CO}_{2}}$ and $\bar{F} \bar{E}_{\mathrm{CO}_{2}}$ remained unchanged.

In the examples presented in Figures 2 to 6, the inspiratory:expiratory ratio had been kept approximately $1: 2$ in each patient. The effect of a change in the inspiratory:expiratory ratio from $1: 4$ to $2: 1$ is shown in Figure 7; the longer inspiration and shorter expiration promoted greater mixing within the circuit and this produced a higher $\mathrm{FI}_{\mathrm{CO}_{2}}$ without changing $\mathrm{FET}_{\mathrm{CO}_{2}}$ and $\mathrm{F} \overline{\mathrm{EO}}_{2}$. 

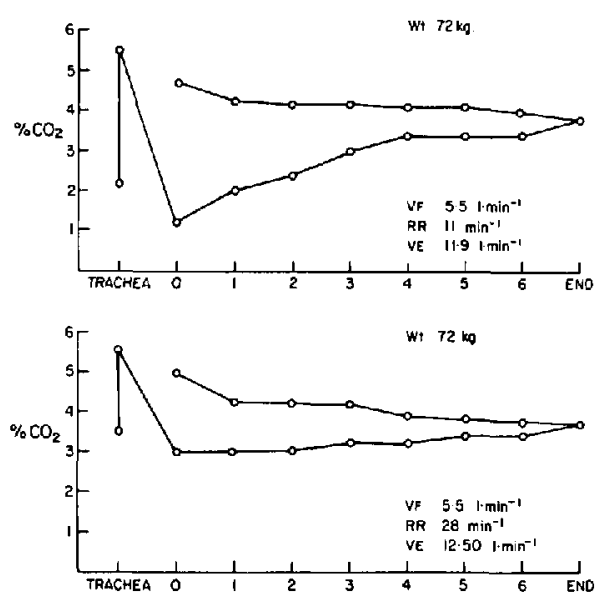

Figure 6 Increase of respiratory rate from $11 \cdot \min ^{-1}$ to $28 \cdot \mathrm{min}^{-1}$ without change in volume of ventilation $\left(\dot{V}_{E}\right)$ or fresh gas flow $\left(\dot{V}_{F}\right)$.
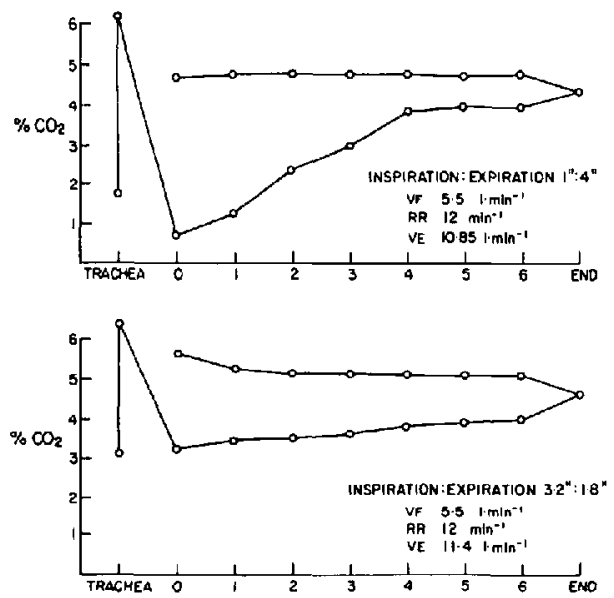

FIGURE 7 Change in inspiration:expiration ratio only increases mixing and $\mathrm{Fi}_{\mathrm{CO}_{2}}$ without a change in $\mathrm{FET}_{\mathrm{CO}_{2}}$ or $\mathrm{FE}_{\mathrm{CO}_{2}}$.

\section{Discussion}

The distribution of carbon dioxide within the breathing tube of the Bain circuit is determined by the degree of mixing that occurs with ventilation. With slow ventilation and a long expiratory pause, a wide space separated the recorded maximum and minimum carbon dioxide values, particularly at the patient end of the circuit near the fresh gas inflow. This space represents a bolus of fresh gas present just before the start of inspiration. Increased mixing produced an approximation of maximum and minimum carbon dioxide concentration. With complete mixing of expired gas and fresh gas there should be a uniform distribution of carbon dioxide throughout the respiratory cycle within the breathing tube at the level of the $\mathbf{F} \overline{\mathbf{E}}_{\mathrm{CO}_{2}}$.

The highest degree of mixing was seen with an increase in RR and $\dot{V}_{E}$ (Figures 2 and 3 ), although an increase in $R R$ alone with an unchanged $\vec{V}_{E}$ (Figure 6) produced almost as much mixing. A change in the inspiratory:expiratory ratio from 1:4 to 2:1, keeping RR and VE constant, caused a lesser degree of mixing (Figure 7), while an augmentation of the tidal volume only at an unchanged RR and inspiratory:expiratory ratio induced the least mixing (Figure 4). The $\mathrm{Fl}_{\mathrm{CO}_{2}}$, as an indicator of rebreathing, changed on each occasion according to the degree of mixing inside the breathing tube; increased mixing raised the $\mathrm{FI}_{\mathrm{CO}_{2}}$ while a type of ventilation that reduced mixing lowered it. With the exception of mixing induced by changes in respiratory rate and inspiratory:expiratory ratio only, the $\mathrm{Fl}_{\left.\mathrm{C}^{(}\right)_{2}}$ increased as $\dot{V}_{E}$ exceeded $\dot{V}_{F}$ and could be lowered if $\dot{V}_{E}$ was reduced toward $\dot{V}_{F}$ (or $\dot{V}_{F}$ increased toward $\dot{V}$ ), as previously shown by Ramanathan, et al. ${ }^{\text {h }}$

There was no correlation between $\mathrm{FI}_{\mathbf{C}^{\prime} \mathrm{O}_{2}}$ and $\mathrm{FET}_{\mathrm{CO}_{2}}$. With changes in rate, volume and phasing the $\mathrm{Fl}_{\mathrm{CO}_{2}}$ changed always independently of $\mathrm{FET}_{\mathrm{CO}_{2}}$ and, under certain conditions. $\mathrm{FI}_{\mathrm{CO}_{2}}$ and $\mathrm{FET}_{\mathrm{CO}_{2}}$ changed in opposite directions (Figures 2 and 4). An increase in $\dot{V}_{F}$ alone, without altering $R R$ and $\dot{V}_{E}$, resulted in a corresponding fall in FET $\mathrm{CO}_{2}$ (and $\mathrm{FE}_{\mathrm{CO}_{2}}$ ), but $\mathrm{FI}_{\mathrm{CO}_{2}}$ declined relatively little, since the change had only slightly altered the carbon dioxide distribution within the circuit (Figure 5). Rebreathing due to the mixing of fresh gas and expired gas did not seem to influence

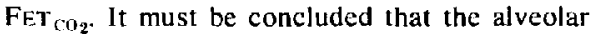
ventilation is controlled only by the fresh gas participating in the gas exchange and unaffected by the degree of admixture of expired gas.

The alveolar ventilation cannot exceed $\dot{V}_{F}$; in fact, it must always be less, as expressed by Conway. ${ }^{16}$

$$
\mathrm{FA}_{\mathrm{AO}_{2}}=\dot{\mathrm{V}} \mathrm{CO}_{2} / \mathrm{f} \cdot \dot{\mathrm{V}}_{\mathrm{F}}
$$

where $f \cdot \dot{V} F$ represents the fraction of fresh gas utilized for the alveolar gas exchange. The volume of gas vented from the circuit is also limited by $\dot{V}_{F}$; during maintenance of anaesthesia the volumes of gas entering and leaving the circuit should be practically equal. 
The volume of gas vented from the circuit is totally independent of $\dot{V}_{E}$; it carries all the carbon dioxide which has been removed from the patient. Consequently the $\mathrm{FE}_{\mathrm{CO}_{2}}$ must depend on carbon dioxide production and $\dot{V} F$ :

$$
\mathrm{FE}_{\mathrm{CO}_{2}}=\dot{\mathrm{VCO}}_{2} / \mathrm{NF}
$$

Since both $\mathrm{FET}_{\mathrm{CO}_{2}}$ and $\mathrm{FE}_{\mathrm{CO}_{2}}$ are directly determined by $\dot{V}_{F}$, it follows that the $\dot{V}_{F}$ which satisfied a given level of alveolar ventilation must always be adequate for the required removal of carbon dioxide from the circuit. The Bain circuit itself, with controlled ventilation, can never be responsible for carbon dioxide retention; accumulation of carbon dioxide can only occur due to an insufficient alveolar ventilation as a result of inadequate $\dot{V}_{F}$ or reduced utilization of $\dot{V}_{F}$.

The utilization of $\dot{V}_{F}$ (or $f$ ) can be estimated by comparing $\mathrm{FA}_{\mathrm{CO}_{2}}$ and $\mathrm{FE}_{\mathrm{CO}_{2} .}{ }^{14}$

$$
\mathrm{f}=\mathrm{F} \vec{E}_{\mathrm{CO}_{2}} / \mathrm{FA}_{\mathrm{CO}_{2}}
$$

Thus $(1-0)$ would represent the ratio of the functional dead space of the combination of patient and circuit. Maximal utilization of ${ }_{F} F$ would require that $\dot{V} E$ is sufficient to transport all fresh gas into the lung. Rose and Froese ${ }^{14}$ have established under the condition set up in their model that the fresh gas utilization was maximal if $\dot{V}_{E}$ exceeded $1.5 \times \dot{V}_{F}$. Any further increase of $\dot{V}_{E}$ over $\dot{V}_{F}$ will no longer influence $\mathrm{FACO}_{2}$ (or $\mathrm{FET}_{\mathrm{CO}_{2}}$; , however, it would increase the degree of mixing and accordingly raise the $\mathrm{FI}_{\mathrm{CO}_{2}}$.

It has been stated that with the Bain circuit the $\mathrm{PadCO}_{2}$ is controlled by rebreathing and Keenan and Boyan ${ }^{17}$ have introduced a factor (VE $\left.\dot{V}_{F}\right) / \dot{V}_{F}$ to indicate rebreathing in a formula designed to predict the $\mathrm{Pa}_{\mathrm{CO}_{2}}$ with the Bain circuit. This view is not compatible with the finding that the utilization of $\dot{V}_{F}$ reaches a plateau and remains unchanged with further increases of $\dot{V}_{E}$ over V.F. It would also not agree with the observation that rebreathing or mixing within the circuit does not affect $\mathrm{FET}_{\mathrm{CO}_{2}}$ nor $\mathrm{FE}_{\mathrm{CO}_{2}}$.

It is concluded that in the Bain circuit with controlled ventilation the degree of mixing of fresh gas and expired gas varies the $\mathrm{FI}_{\mathrm{CO}_{2}}$ but has no effect on alveolar ventilation or carbon dioxide elimination. $\mathrm{FET}_{\mathrm{CO}_{2}}$ and $\mathrm{FE}_{\mathrm{CO}_{2}}$ are controlled only by $\dot{V}_{F}$ and its utilization. A $\dot{V}_{F}$ which satisfies the patient's alveolar ventilation must also remove the required volume of carbon dioxide; the circuit per se can never cause retention because of an unfavorable carbon dioxide distribution. In contrast to the circle absorber, where carbon dioxide is eliminated in the circuit,

carbon dioxide is transported through the Bain circuit and eliminated at the venting valve.

\section{ABbreViations}

$\mathrm{FET}_{\mathrm{CO}_{2}}$

$\mathrm{FACO}_{2}$

$\mathrm{FI}_{\mathrm{CO}_{2}}$

$\mathrm{FE}_{\mathrm{CO}_{2}}$

$\mathrm{Pa}_{\mathrm{CO}}$

VF

$\dot{V} E$

$\dot{\mathrm{V}} \mathrm{CO}_{2}$

RR

Inspiratory:

expiratory

ratio end-tidal carbon dioxide concentration.

alveolar carbon dioxide concentration.

lowest carbon dioxide concentration recorded in the trachea during inspiration.

Mean carbon dioxide concentration in gas eliminated from the circuit.

arterial carbon dioxide tension. volume per minute of fresh gas entering the circuit.

expired minute volume measured at the endotracheal tube.

carbon dioxide output per minute. respiratory rate.

ratio time of inspiration to time of expiration.

\section{REFERENCES}

I. Bain, J.A. \& Spoerel, W.E. A streamlined anaesthetic breathing circuit. Canad. Anaesth. Soc. J. 19: 426 (1972).

2. Mapleson, W.W. The elimination of rebreathing in various semi-closed anaesthetic circuits. Brit. J. Anaesth. 26: 323 (1954).

3. SYKES, M.K. Rebreathing circuit: a review. Brit. J. Anaesth. 40: 666 (1968).

4. Conway, C.M. Anaesthetic circuits. In Scurr, C. and Feldman, S. Scientific Foundation of Anaesthesia, 2nd edition. W. Heinemann Medical Books Ltd., London, 1974.

5. Conway, C.M., Seeley, H.F. \& Barnes, P.K. Spontaneous ventilation with the Bain anaesthetic system. Brit. J. Anaesth. 49: 1245 (1977).

6. Ramanathan. S., Chalan, J., Capan, L., PATEl, C. \& TURNDORF, H. Rebreathing characteristics of the Bain anesthesia circuit. Anesth. \& Analg. 56: 822 (1977).

7. Rose, D.K.. Byrick, R.J. \& Froese, A.B. Carbon dioxide elimination during spontaneous ventilation with a modified Mapleson D system: studies in a lung model. Canad. Anaesth. Soc. J. 25: 353 (1978).

8. UNGERER, M.J. A comparison between the Bain and Magill anaesthetic systems during spontaneous breathing. Canad. Anaesth. Soc. J. 25: 122 (1978).

9. Baraka, A. Pa $\mathrm{CO}_{2}$ control by fresh gas flow during controlled ventilation with a semi-open circuit. Brit. J. Anaesth. 41 : 527 (1969).

10. Bain, J.A. \& Spoerel, W.E. Ptediction of arterial 
carbon dioxide tension with a modified Mapleson D system. Canad. Anaesth. Soc. J. 22: 34 (1975).

11. Bain, J.A. \& Spoerel, W.E. Low flow anaesthesia utilizing a single limb circuit. In Aldrete, $A$. (Edit.) Low Flow and Closed System Anaesthesia. Grune \& Stratton, 1979.

12. Henville, J.D. \& Adams, A.P. The Bain anaesthetic system: an assessment during controlled ventilation. Anaesthesia 32: 247 (1976).

13. Pollard, B. \& Gibs, D.B. Some adverse physiological effects of hypocarbia and methods of maintaining normocarbia during controlled ventilation-a review. Anaesth. \& Intensive Care. 5: 113 (1977).
14. Rose, K. \& Froese, A. Factors determining $\mathrm{Pa}_{\mathrm{CO}_{2}}$ during controlled ventilation with a T-piece. Canad. Anaesth. Soc. J. 26: 104 (1979).

15. Seeley, H.F., Barnes, P.K. \& Conway, C.M. Controlled ventilation with the Mapleson D system. Brit. J. Anaesth. 49: 107 (1977).

16. CONWAY, C.M. Alveolar gas relationships during the use of semi-closed rebreathing anaesthetic systems. Brit. J. Anaesth. 48: 865 (1976).

17. KeEnan, R.L. \& Boyan. C.P. How rebreathing anaesthetic systems control $\mathrm{Pa}_{\mathrm{Co}_{2}}$ : Studies with a mechanical and mathematical model. Canad. Anaesth. Soc. J. 25: 117 (1978).

\section{RÉSUMÉ}

La distribution du $\mathrm{CO}_{2}$ à l'intérieur d'un circuit de Bain a été étudiée chez 14 patients en respiration contrôlée. Pour ce faire, on a installé sept sites de prélèvements le long d'un circuit et des échantillons gazeux ont également été prélevés à l'appareil d'anesthésie, ainsi qu'au bout du tube trachéal (au moyen d'un petit cathéter); les mesures de la $\mathrm{PCO}_{2}$ ont été effectuées au moyen d'un spectromètre de masse. Après 30 minutes d'anesthésie stable à l'halothane or à l'éthrane, l'on a déterminé la $\mathrm{PCO}_{2}$ minimale et maximale à chacun des sites décrits plus haut. On a ensuite modifié l'un des paramètres suivants en conservant les autres constants: volume courant, rapport inspiration-expiration, fréquence respiratoire avec ou sans modification du volume minute, apport de gaz frais. On a refait les mesures au moins 20 minutes plus tard. Pour fins de comparaisons, on n'a considéré que les variations chez un mème sujet.

Les résultats indiquent que lorsque le volume minute expiré (VE) était plus grand que l'apport de gaz frais $\left(\hat{\mathrm{V}}_{\mathrm{F}}\right)$, le $\mathrm{CO}_{2}$ de fin d'expiration $\left(\mathrm{FET}_{\mathrm{CO}_{2}}\right.$ ) et la concentration moyenne de $\mathrm{CO}_{2}$ éliminée du circuit $\left(\mathrm{F} \hat{\mathrm{E}}_{\mathrm{CO}}\right.$ ) ne dépendaient que de l'apport de gaz frais et son utilisation. On pouvait faire varier la concentration minimale du $\mathrm{CO}_{2}$ inspiré $\left(\mathrm{FI}_{\mathrm{CO}_{2}}\right)$ indépendamment de la $\mathrm{FET}_{\mathrm{CO}_{2}}$ et de la $\mathrm{FE}_{\mathrm{CO}_{2}}$ en modifiant la fréquence respiratoire (avec ou sans changement du volume minute de $\mathrm{CO}_{2}$ expiré), ou en modifiant le volume courant, ou encore le rapport inspiratoire, tous des facteurs qui influencent le taux de rebreathing ou le mélange des gaz expirés avec les gaz frais dans le circuit. La concentration minimale de fin d'expiration se rapprochera de la $\mathrm{F} \bar{E}_{\mathrm{CO} y}$, d'autant plus que le mélange gaz expirés-gaz frais est plus complet.

Il est conclu qu'en respiration contrôlée, la distribution du $\mathrm{CO}_{2}$ à travers le circuit de Bain et le $\mathrm{CO}_{2}$ inspiré n'ont pas d'influence sur le $\mathrm{CO}_{2}$ alvéolaire ou sur l'élimination du circuit du $\mathrm{CO}_{2}$. 